\section{(2) OPEN ACCESS}

\title{
Cardiovascular disease in homeless versus housed individuals: a systematic review of observational and interventional studies
}

\author{
Nader James Al-Shakarchi (1) ,' Hannah Evans, ${ }^{2}$ Serena A Luchenski, ${ }^{3}$ Alistair Story, ${ }^{2,4}$ \\ Amitava Banerjee (10) 2,5,6
}

- Additional material is published online only. To view, please visit the journal online (http://dx.doi.org/10.1136/ heartjnl-2020-316706).

${ }^{1}$ Medical School, University College London, London, United Kingdom

${ }^{2}$ Institute of Health Informatics, University College London, London, United Kingdom ${ }^{3}$ Institute of Epidemiology and Health Care, University College London, London, United Kingdom

${ }^{4}$ Find and Treat Service, University College London Hospitals NHS Foundation Trust, London, UK

${ }^{5}$ Department of Cardiology, Barts Health NHS Trust, London, United Kingdom ${ }^{6}$ Department of Cardiology, University College London Hospitals NHS Foundation Trust, London, United Kingdom

\section{Correspondence to}

Dr Amitava Banerjee, Institute of Health Informatics, University College London, London NW1 2DA, UK;

ami.banerjee@ucl.ac.uk

Received 13 February 2020

Revised 6 May 2020

Accepted 15 May 2020

Published Online First

14 July 2020

\section{SLinked}

- http://dx.doi.org/10.1136/ heartjnl-2020-317224

Check for updates

(C) Author(s) (or their employer(s)) 2020. Re-use permitted under CC BY-NC. No commercial re-use. See rights and permissions. Published by BMJ.

To cite: Al-Shakarchi NJ, Evans $\mathrm{H}$, Luchenski SA, et al. Heart 2020;106:1483-1488.

\section{ABSTRACT}

Objectives To identify: (i) risk of cardiovascular disease (CVD) in homeless versus housed individuals and (ii) interventions for CVD in homeless populations.

Methods We conducted a systematic literature review in EMBASE until December 2018 using a search strategy for observational and interventional studies without restriction regarding languages or countries. Meta-analyses were conducted, where appropriate and possible. Outcome measures were all-cause and CVD mortality, and morbidity.

Results Our search identified 17 articles (6 case-control, 11 cohort) concerning risk of CVD and none regarding specific interventions. Nine were included to perform a meta-analysis. The majority $(13 / 17,76.4 \%)$ were high quality and all were based in Europe or North America, including 765459 individuals, of whom 32721 were homeless. 12/17 studies were pre-2011. Homeless individuals were more likely to have CVD than nonhomeless individuals (pooled OR 2.96; $95 \% \mathrm{Cl} 2.80$ to 3.13; $p<0.0001$; heterogeneity $\left.p<0.0001 ;\left.\right|^{2}=99.1 \%\right)$ and had increased CVD mortality (age-standardised mortality ratio range: 2.6-6.4). Compared with nonhomeless individuals, hypertension was more likely in homeless people (pooled OR 1.38-1.75, $p=0.0070$; heterogeneity $p=0.935 ; I^{2}=0.0 \%$ ).

Conclusions Homeless people have an approximately three times greater risk of CVD and an increased CVD mortality. However, there are no studies of specific pathways/interventions for CVD in this population. Future research should consider design and evaluation of tailored interventions or integrating CVD into existing interventions.

\section{INTRODUCTION}

Economic and political policies have increased the burden of homelessness in many countries. Homeless individuals experience social exclusion and high burden of morbidity and mortality, alongside other 'inclusion health' populations, such as individuals with substance use disorders, sex workers and imprisoned individuals. Clinical and public health strategies to manage the care of homeless people have largely focused on communicable diseases, drugs and alcohol, mental illness and acute crisis management. ${ }^{1}$

Chronic non-communicable diseases, particularly cardiovascular diseases (CVD), represent a major cause of excess mortality and morbidity within these populations, ${ }^{2-4}$ just as they do in the general population globally. ${ }^{5}$ For CVD in homeless individuals, specific risks across individual diseases (eg, coronary vs peripheral arterial disease) are unknown and targeted management guidelines do not exist. ${ }^{6}$ Management pathways for housed individuals may not be effective in homeless populations, and may exclude them. Observational studies are required to describe the disease burden and the healthcare need. Based on these data, interventional studies, ideally randomised controlled trials, can inform treatment and prevention in homeless people, but specific data are limited. ${ }^{1}$

Several recent studies have shown the importance of CVD by self-report in hospital discharge and at community level in homeless people. ${ }^{2-47}$ The burden of CVD in homeless individuals is demonstrated to be high but has not been systematically studied. ${ }^{8-10}$ Without an appraisal of interventional studies, strategies to address CVD in homeless individuals remain unclear. A recent meta-analysis found that premature death was up to 12 times more likely in inclusion health populations than in housed individuals, ${ }^{2}$ but studies of homelessness were not separately analysed. We performed a systematic review of interventional and observational studies of CVD in homeless, compared with housed individuals to establish if available therapies work, and inform design, evaluation and implementation of effective interventions.

\section{METHODS}

We adhered to the Preferred Reporting Items for Systematic Reviews and Meta-Analyses guidelines. ${ }^{11}$ Our research questions were: (i) 'Do homeless individuals have higher risk of CVD than housed individuals?' and (ii) 'In homeless patients with CVD, are there interventions that reduce all-cause mortality and/or CVD mortality and/or admission rates? If so, which are the most effective interventions?' The questions were used in Population, Intervention, Control/Comparator, Outcome (PICO) format ${ }^{12}$ to develop search terms.

\section{Search strategy}

We searched EMBASE between 1 January 1947 and 31 December 2018 using search terms relevant to CVD and homelessness (detailed search terms in online supplementary appendix), supplemented by manual search of reference lists of relevant publications and input from clinical and academic experts in homeless populations. There were no language restrictions. 


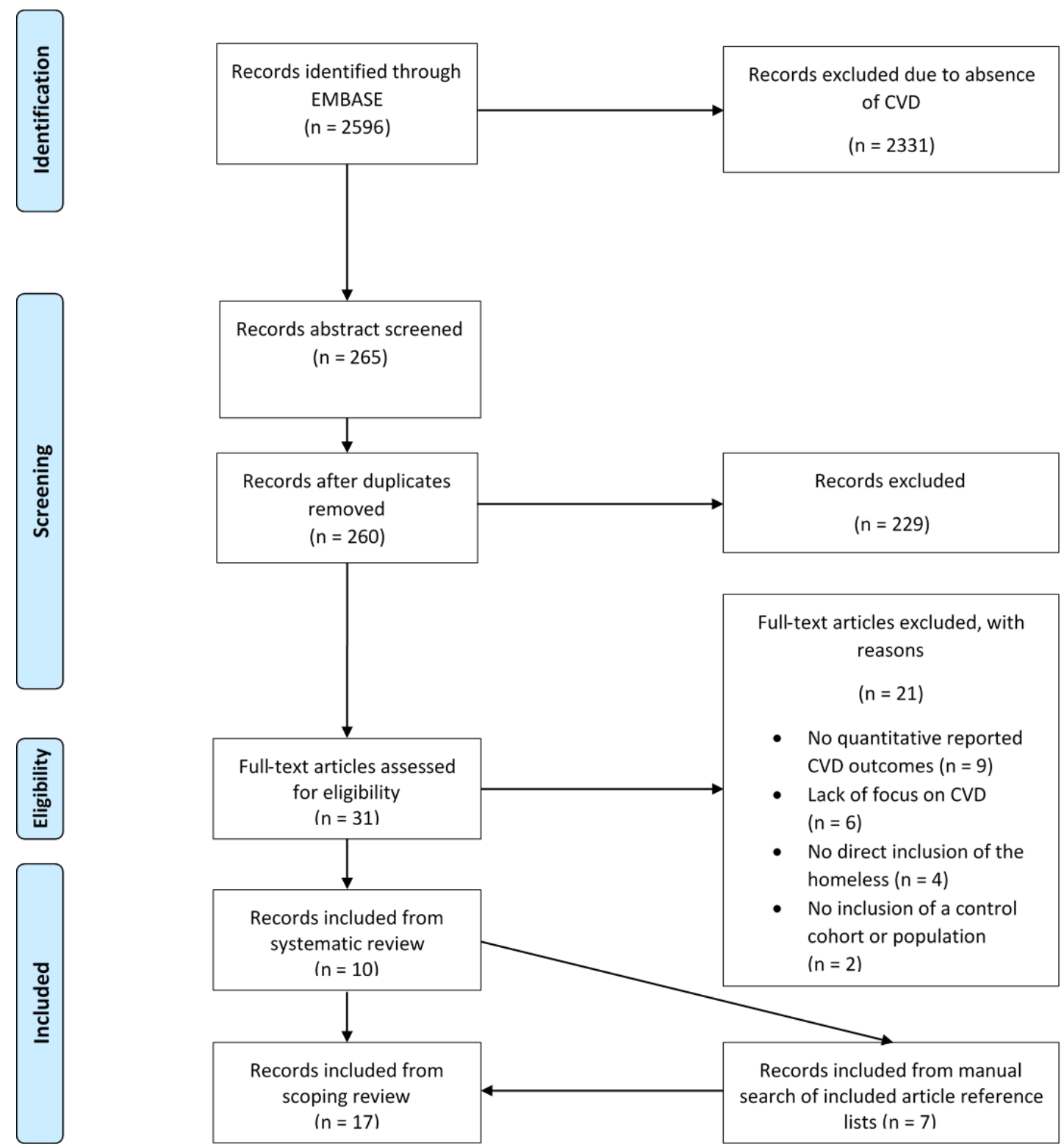

Figure 1 The Preferred Reporting Items for Systematic Reviews and Meta-Analyses diagram representing the systematic literature search.

\section{Inclusion/Exclusion criteria}

Observational and interventional studies were included if the following criteria were met: 1) at least one reported CVD outcome, 2) inclusion of homeless individuals with separate reported outcomes and 3) inclusion of a control cohort or population. Published abstracts were included. All other article types (eg, letters to the editor, editorials, replies and commentaries) were excluded.

\section{Article selection}

Titles, then abstracts and then full manuscripts of identified articles were sequentially screened by two investigators and disagreements were resolved by a third reviewer (from NJA-S, $\mathrm{HE}$ and $\mathrm{AB}$ ) (figure 1).

\section{Data extraction}

Extracted data included study population, country, CVD outcomes, duration of follow-up and were collected through a standardised proforma. Study quality was assessed using the Newcastle-Ottawa Scale. ${ }^{13}$

\section{Data analysis}

All analyses were conducted using Stata (V.13) and visualised using MedCalc (V.19.0.6). Primary outcomes were all-cause and CVD mortality, and secondary outcomes were admission and readmission rates, and CVD morbidity. If possible, reported $\mathrm{OR}$, rate ratio (RR), $\mathrm{HR}$ and/or age-standardised mortality rate (ASMR) with 95\% CI were included or calculated from available data. Subgroup analyses were conducted for sex, ethnic group and age, where possible. Pooled ORs were calculated. Random effects models were used and heterogeneity estimated. Analyses were further stratified by geographic region, where possible.

\section{RESULTS}

\section{Findings from search}

Our search identified 2596 articles. After title review, 265 abstracts were selected, of which 5 were duplicates (figure 1), yielding 31 articles for full-text review. Of these, 10 met inclusion criteria and a further 7 articles (retrieved by manual search) were also included. Reasons for exclusion at the full-text stage were: 1) no reported CVD outcomes $(n=15), 2)$ no direct 
Table 1 Summary of the studies $(n=17)$ of cardiovascular mortality and morbidity in homeless populations

\begin{tabular}{|c|c|c|c|c|c|c|c|c|}
\hline Study & $\begin{array}{l}\text { Homeless study } \\
\text { population (age in } \\
\text { years) }\end{array}$ & $N$ & $\%$ male & Control population & Setting, Country & Year of study & Outcome & Findings \\
\hline Roncarati et a $l^{9}$ & $\begin{array}{l}\text { Unsheltered adults } \\
(\geq 18)\end{array}$ & 445 & 72 & $\begin{array}{l}\text { Non-homeless } \\
\text { Massachusetts adult } \\
\text { population or adult } \\
\text { Boston who slept } \\
\text { primarily in shelters }\end{array}$ & $\begin{array}{l}\text { Boston, Massachusetts, } \\
\text { USA }\end{array}$ & $2000-2009$ & CVD defined by ICD-10 & $\begin{array}{l}\text { ASMR: } 6.4(95 \% \mathrm{Cl} 3.9 \\
\text { to } 9.9)\end{array}$ \\
\hline Corless et $\left.a\right|^{30}$ & $\begin{array}{l}\text { Adults enrolled } \\
\text { in a healthcare } \\
\text { programme } \\
\text { (unspecified) }\end{array}$ & 28 & 79 & $\begin{array}{l}\text { Housed individuals } \\
\text { matched by age, stroke } \\
\text { type, gender and year }\end{array}$ & Portland, Oregon, USA & 2009-2016 & Delayed hospital arrival time & $\begin{array}{l}\text { Adjusted HR: } 0.67 \\
(p=0.056)\end{array}$ \\
\hline Slockers et al (S1) & Adults $(\geq 20)$ & 2130 & 88 & $\begin{array}{l}\text { General population of } \\
\text { Rotterdam }\end{array}$ & $\begin{array}{l}\text { Rotterdam, The } \\
\text { Netherlands }\end{array}$ & $2001-2010$ & CVD defined by ICD-10 & $\begin{array}{l}\text { HR: } 1.39(95 \% \mathrm{Cl} 0.81 \\
\text { to } 2.4) \\
\text { ASMR: } 3.7(95 \% \mathrm{Cl} 2.8 \\
\text { to } 4.7)\end{array}$ \\
\hline Schinka et al (S2) & Veterans (18-54) & 23898 & 96 & Non-homeless veterans & $\begin{array}{l}\text { Veterans Health } \\
\text { Administration, USA }\end{array}$ & $2000-2003$ & CVD defined by ICD-10 & HR: $2.8(95 \% \mathrm{Cl} 2.6$ to 3.1$)$ \\
\hline Stenius-Ayoade et al (S3) & Men $(\geq 21)$ & 617 & 100 & $\begin{array}{l}\text { Age-matched general } \\
\text { population }\end{array}$ & Helsinki, Finland & 2004-2014 & CVD defined by ICD-10 & $\begin{array}{l}\text { Age-standardised HR: } 2.5 \\
(95 \% \mathrm{Cl} 1.7 \text { to } 3.8)\end{array}$ \\
\hline Asgary et al (S4) & $\begin{array}{l}\text { Adults enrolled } \\
\text { in a healthcare } \\
\text { programme (28-92) }\end{array}$ & 177 & 75 & $\begin{array}{l}\text { Random sample of } \\
\text { hypertensive patients }\end{array}$ & $\begin{array}{l}\text { New York City, New } \\
\text { York, USA }\end{array}$ & 2013-2014 & $\begin{array}{l}\text { Uncontrolled blood pressure } \\
\geq 140 / 90 \mathrm{~mm} \mathrm{Hg}\end{array}$ & $\begin{array}{l}\mathrm{OR}=1.34(95 \% \mathrm{Cl} 0.61 \\
\text { to } 2.93)\end{array}$ \\
\hline Schinka et al (S5) & Veterans $(\geq 55)$ & 4475 & 99 & $\begin{array}{l}\text { Non-homeless veterans } \\
\geq 55 \text { years }\end{array}$ & $\begin{array}{l}\text { Veterans Health } \\
\text { Administration, USA }\end{array}$ & $2000-2011$ & CVD defined by ICD-10 & $\begin{array}{l}\text { Leading category of death } \\
\text { ( } 33 \% \text { of all deaths) }\end{array}$ \\
\hline Naszydiowska et al (S6) & Adults (18-79) & 614 & 82 & $\begin{array}{l}\text { Age-matched group of } \\
\text { housed adults }\end{array}$ & Poland & 2015 & $\begin{array}{l}\text { Uncontrolled blood pressure (not } \\
\text { defined) }\end{array}$ & $\begin{array}{l}\text { Men percentage difference: } \\
30 \% \\
\text { Women percentage } \\
\text { difference: } 27 \%\end{array}$ \\
\hline Baggett et al (S7) & $\begin{array}{l}\text { Adults in a } \\
\text { healthcare } \\
\text { programme ( } \geq 18)\end{array}$ & 28033 & 66 & $\begin{array}{l}\text { General population, } \\
\text { Massachusetts }\end{array}$ & $\begin{array}{l}\text { Boston, Massachusetts, } \\
\text { USA }\end{array}$ & $2003-2008$ & CVD defined by ICD-9 or ICD-10 & $\begin{array}{l}\text { Second leading cause of } \\
\text { death ( } 16 \% \text { of all deaths) }\end{array}$ \\
\hline Vijayaraghavan et al (S8) & $\begin{array}{l}\text { Adults in unstable } \\
\text { housing }(\geq 18)\end{array}$ & 370 & 55 & $\begin{array}{l}\text { Baseline population } \\
\text { was the same cohort in } \\
\text { 1990-1991 }\end{array}$ & 4 cities in the USA & $1990-2010$ & $\begin{array}{l}\text { Uncontrolled blood pressure } \\
\geq 140 / 90 \mathrm{~mm} \mathrm{Hg}\end{array}$ & $\begin{array}{l}\text { Adjusted RR: } 1.1(95 \% \mathrm{Cl} \\
0.9 \text { to } 1.5)\end{array}$ \\
\hline Beijer et al (\$9) & Adults ( $\geq 18)$ & 2283 & 77 & $\begin{array}{l}\text { General population of } \\
\text { Stockholm County }\end{array}$ & Stockholm, Sweden & 1995-2005 & CVD defined by ICD-8 or ICD-9 & $\begin{array}{l}\text { Men: ASMR RR: } 2.6 \text { ( } 95 \% \\
\text { Cl } 2.1 \text { to } 3.2 \text { ) } \\
\text { Women: ASMR RR: } 3.3 \\
\text { (95\% Cl } 1.8 \text { to } 3.7 \text { ) }\end{array}$ \\
\hline $\begin{array}{l}\text { Beijer and Andreasson } \\
\text { (S10) }\end{array}$ & Adults $(\geq 20)$ & 1704 & 80 & $\begin{array}{l}\text { Random sample from } \\
\text { general population of } \\
\text { Sweden }\end{array}$ & Stockholm, Sweden & 1996-1997 & CVD defined by ICD-10 or 9 & $\begin{array}{l}\text { Men: RR: } 1.66(95 \% \mathrm{Cl} \\
1.37 \text { to } 2.02) \\
\text { Women: } \mathrm{RR}: 1.54(95 \% \mathrm{Cl} \\
0.88 \text { to } 2.68)\end{array}$ \\
\hline Morrison (S11) & Adults ( $\geq 18)$ & 6757 & 65 & $\begin{array}{l}\text { Age-matched and } \\
\text { sex-matched random } \\
\text { sample of the local non- } \\
\text { homeless population in } \\
\text { the Greater Glasgow }\end{array}$ & Glasgow, Scotland & 2000-2005 & CVD defined by ICD-10 & $\begin{array}{l}\text { Age-adjusted and sex- } \\
\text { adjusted HR: } 1.8(95 \% \mathrm{Cl} \\
1.1 \text { to } 2.9)\end{array}$ \\
\hline Hwang et al ${ }^{10}$ & $\begin{array}{l}\text { Adults: homeless and } \\
\text { marginally housed } \\
(\geq 25)\end{array}$ & 15100 & 70 & $\begin{array}{l}\text { Reference population } \\
\text { from Canada Census }\end{array}$ & Canada & $1991-2001$ & CVD defined by ICD-9 & $\begin{array}{l}\text { Men: age-adjusted RR: } 1.7 \\
\text { (95\% Cl } 1.6 \text { to } 1.8) \\
\text { Women: age-adjusted RR: } \\
1.6(95 \% \mathrm{Cl} 1.4 \text { to } 1.8)\end{array}$ \\
\hline Hwang (S12) & Men $(\geq 18)$ & 8933 & 100 & $\begin{array}{l}\text { General population } \\
\text { in Toronto, Ontario, } \\
\text { Canada }\end{array}$ & Toronto, Ontario, Canada & 1995-1997 & CVD defined by ICD-9 & $\begin{array}{l}\text { 25-44 years: RR: } 2.4(95 \% \\
\text { Cl } 0.9 \text { to } 6.6) \\
\text { 45-64 years: RR: } 1.4(95 \% \\
\text { Cl } 0.7 \text { to } 2.9)\end{array}$ \\
\hline Hwang et al (S13) & $\begin{array}{l}\text { Adults enrolled } \\
\text { in a healthcare } \\
\text { programme }(\geq 18)\end{array}$ & 17292 & 68 & $\begin{array}{l}\text { General population in } \\
\text { Boston, Massachusetts, } \\
\text { USA }\end{array}$ & $\begin{array}{l}\text { Boston, Massachusetts, } \\
\text { USA }\end{array}$ & 1988-1993 & CVD defined by ICD-9 & $\begin{array}{l}\text { Men } 25-44 \text { years: race- } \\
\text { adjusted RR: } 3.5 \text { ( } 95 \% \text { Cl } \\
2.1 \text { to 5.6) } \\
\text { Men 45-64 years: race- } \\
\text { adjusted RR: } 1.5 \text { ( } 95 \% \text { Cl } \\
1.1 \text { to } 2.1) \\
\text { Women } 25-44 \text { years: race- } \\
\text { adjusted RR: } 2.4 \text { (95\% Cl } \\
\text { 0.7 to 7.7) } \\
\text { Women 45-64 years: race- } \\
\text { adjusted RR: } 1.2 \text { (95\% Cl } \\
0.4 \text { to 3.3) }\end{array}$ \\
\hline Hibbs et al (S14) & Adults ( $\geq 15)$ & 10715 & 63 & $\begin{array}{l}\text { General population in } \\
\text { Philadelphia, USA }\end{array}$ & Philadelphia, USA & 1985-1988 & Heart disease (not defined) & $\begin{array}{l}\text { Second leading cause of } \\
\text { death ( } 19 \% \text { of all deaths) }\end{array}$ \\
\hline
\end{tabular}

ASMR, age-standardised mortality rate; CVD, cardiovascular disease; ICD, International Classification of Diseases; RR, rate ratio.

inclusion of homeless individuals $(\mathrm{n}=4)$ or 3 ) no inclusion of a control cohort or population $(n=2)$. Therefore, 17 studies were included in total. There were no intervention studies (comparative or otherwise) of CVD in homeless individuals.

\section{Study characteristics}

Included studies were from seven countries (table 1). The USA contributed the majority of studies $(n=9)$, while Sweden and Canada both contributed two studies, and the remaining countries (Scotland, The Netherlands, Finland and Poland) all contributed one study. The control population either consisted of the general population $(n=8)$, non-homeless individuals $(n=3)$, unstable housing $(n=1)$, a random sample of housed hypertensive patients $(n=1)$, homeless patients not enrolled in a health programme $(n=1)$ or the general population $(n=1)$. 


\begin{tabular}{|c|c|c|c|c|}
\hline & $\begin{array}{l}\text { High quality } \\
(\%) \\
(\text { score >6) }\end{array}$ & $\begin{array}{l}\text { Medium quality } \\
(\%) \\
\text { (score 5-6) }\end{array}$ & $\begin{array}{l}\text { Low quality } \\
(\%) \\
(\text { score <5) }\end{array}$ & $\begin{array}{l}\text { Mean score } \\
\text { (maximum 9) }\end{array}$ \\
\hline \multicolumn{5}{|l|}{ Study design } \\
\hline All $(n=17)$ & 76.5 & 17.6 & 5.9 & $6.9(1.2)$ \\
\hline Cohort (n=11) & 81.8 & 9.1 & 9.1 & $7.2(0.9)$ \\
\hline \multirow[t]{2}{*}{ Case-control $(n=6)$} & 66.7 & 16.7 & 16.7 & $6.3(1.5)$ \\
\hline & $\begin{array}{l}\text { Selection } \\
\text { (maximum 4) }\end{array}$ & $\begin{array}{l}\text { Comparability } \\
\text { (maximum 2) }\end{array}$ & $\begin{array}{l}\text { Outcome or } \\
\text { exposure } \\
\text { (maximum 3) }\end{array}$ & $\begin{array}{l}\text { Mean total } \\
\text { score } \\
\text { (maximum 9) }\end{array}$ \\
\hline \multicolumn{5}{|l|}{ Study design } \\
\hline Cohort & $2.6(0.7)$ & $2(0)$ & $2.5(0.7)$ & $7.2(0.9)$ \\
\hline Case-control & $2.5(1.2)$ & $1.8(0.4)$ & $2(0)$ & $6.3(1.5)$ \\
\hline \multicolumn{5}{|l|}{ Year of publication } \\
\hline 1999 or earlier & $2(0)$ & $2(0)$ & $3(0)$ & $7(0)$ \\
\hline $2000-2009$ & $2.25(0.5)$ & $2(0)$ & $2.5(0.6)$ & $6.8(0.5)$ \\
\hline 2010 or later & $2.8(1.0)$ & $1.9(0.3)$ & $2.2(0.6)$ & $6.9(1.4)$ \\
\hline
\end{tabular}

The mean with $\mathrm{SD}$ in brackets is shown where applicable.

The most common CVD outcome measure was the development of circulatory disease $(n=12)$, as defined by International Classification of Diseases, Tenth Revision (ICD-10) or earlier versions. Other CVD outcomes included the development of hypertension or length of hospital stay. Reporting of summary measures was heterogeneous, including ASMR, HR, RR, OR and proportion of homeless individuals with CVD. Ten studies reported specific CVD outcomes including cerebrovascular disease $(n=5)$, ischaemic heart disease $(n=3)$ and hypertension $(n=2)$.
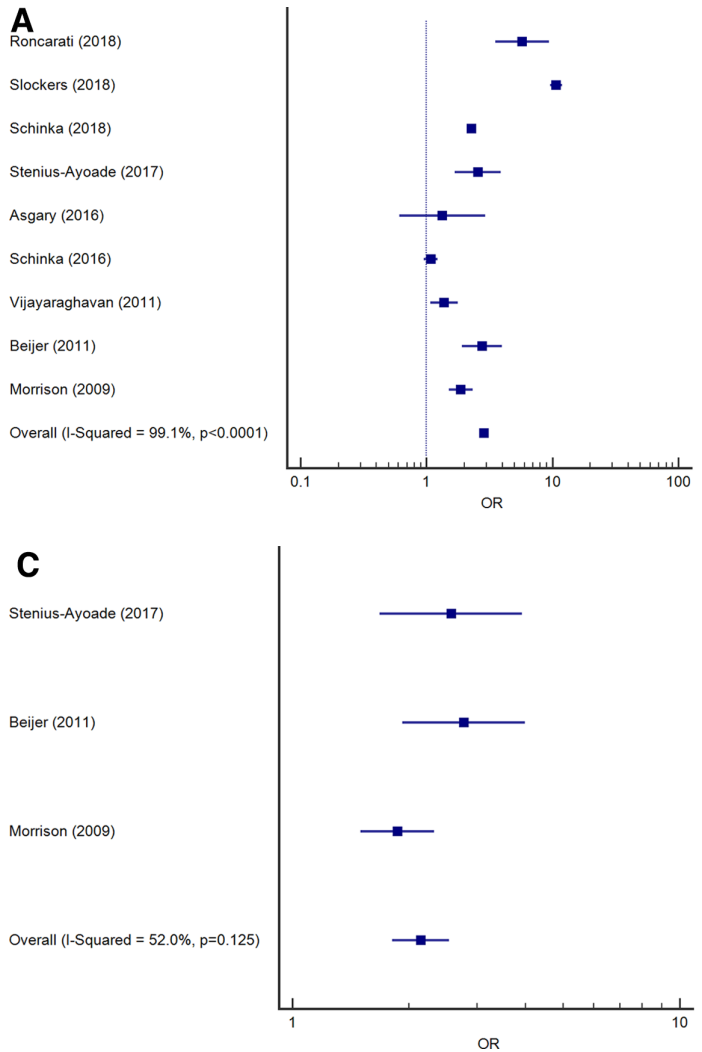

Figure 2 Forest plots of ORs of cardiovascular disease (CVD) (International Classification of Diseases, Tenth Revision definition) in homeless vs housed individuals from (A) all studies in meta-analysis $(n=9)$, (B) North American studies $(n=6)$ and (C) European studies $(n=3)$. (D) Forest plot of ORs of hypertension (a subset of CVD) ( $n=2)$.

\section{Quality assessment}

Table 2 shows quality assessment for both cohort $(n=11)$ and case-control studies $(n=6)$ (mean scores of 7.2 and 6.3, respectively) (table 2). According to year of publication, included studies also generated similar mean scores with studies from 1999 or earlier, 2000-2009, and 2010 or later resulting in scores of 7.0, 6.8 and 6.9, respectively (table 2).

\section{Summary of cardiovascular disease findings}

Table 1 illustrates results obtained from all 17 included studies. Of 14 studies with data which could be analysed, 10 (71.4\%) found that homeless individuals have significantly greater burden of CVD compared with a control population.

Figure 2 shows meta-analyses of the nine studies of CVD defined by ICD-10 classification. CVD was overall more likely in homeless than non-homeless individuals but with significant heterogeneity between studies (pooled OR 2.96, 95\% CI 2.80 to $3.13 ; p<0.0001$; heterogeneity $p<0.0001$ ) (figure 2). The same result was found if only European studies were included, but with no significant heterogeneity (OR 2.84, $95 \%$ CI 2.63 to $\left.3.06 ; \mathrm{p}<0.001, \mathrm{I}^{2}=52.0 \%, \mathrm{p}=0.125\right)$ figure 3. North American studies showed significant heterogeneity, but overall increased CVD in homeless individuals (OR 2.86, $95 \%$ CI 2.64 to $\left.3.07 ; \mathrm{p}<0.001, \mathrm{I}^{2}=61.0 \%, \mathrm{p}=0.036\right)$. Hypertension was more likely in homeless, relative to non-homeless populations (pooled OR 1.38-1.75, p =0.0070; heterogeneity $\mathrm{p}=0.935)$. There was a predominance of studies with a high proportion of men (range: $72 \%-100 \%$ ), which is agreement with 14 of the 17 included studies that possess a mostly male population (table 1 ).
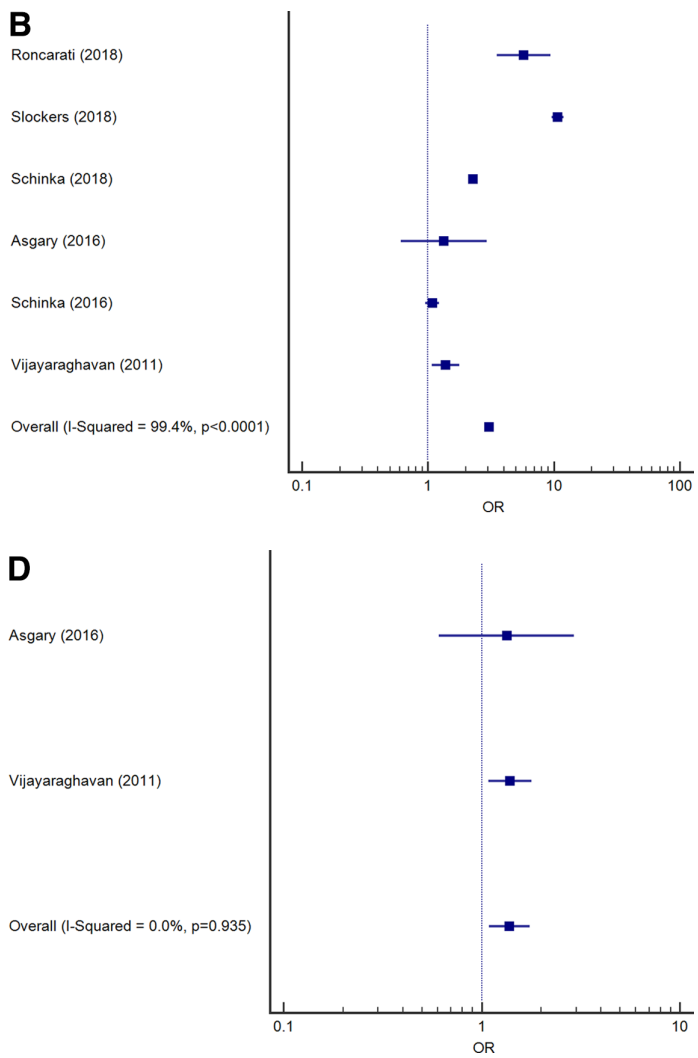


\section{DISCUSSION}

In our study systematically reviewing both observational and interventional studies of management of CVD in homeless populations, there are three main findings. First, the mortality and morbidity associated with CVD in homeless populations is threefold more than housed populations (OR 2.96, 95\% CI 2.80 to $3.13 ; p<0.0001$; heterogeneity $p<0.0001)$. Second, there are no interventional studies examining CVD management in homeless populations. Third, data are limited with respect to CVD in homeless populations by number of studies, year of study, distribution of countries examined and subtypes of CVD.

Despite limited available data, the majority of observational studies $(76.4 \%)$ were high quality (all of the studies included in our meta-analyses). Hence, our European and the US estimates of CVD in homeless populations are likely to be robust, and are consistent with previous studies, ${ }^{8}$ as well as a recent meta-analysis which reported increased all-cause mortality in inclusion health populations (ASMRs 3.0-11.6). ${ }^{2}$ There are likely to be multiple potential causes of the association between homelessness and increased CVD risk, including multiple social (eg, health literacy) and environmental determinants, and acute challenges (health, social and structural) which are prioritised above chronic disease management. There are several unique healthcare challenges associated with homeless populations, including high smoking rates, ${ }^{14} 15$ nutritional deficiencies, ${ }^{16}$ illicit drug use ${ }^{14}$ and increased structural, professional and service design barriers, ${ }^{17} 18$ all of which are likely to be relevant as potential targets for action against CVD. ${ }^{19}$ Socioeconomic determinants of health, or the 'causes of the causes' continue to be neglected, perhaps none more than homelessness. ${ }^{20}$ The combination of lack of specific interventions and lack of specific evidence throughout the prevention pathway in the homeless population leads to a double neglect of CVD. Current guidelines for homeless healthcare services ${ }^{21}$ have overlooked care for chronic and non-communicable diseases until now. Specific interventions for CVD may not be necessarily effective and may be counterproductive in a population with complex, multisectoral health and social needs. Conversely, existing treatment services for CVD are unlikely to accessible the homeless population, particularly since data about individual types of CVD are lacking. Specialist care generally means specialist primary care in the homeless context rather than specialist secondary or tertiary care, but there is an inadequate evidence base, whether by trials, observational data or implementation science. However, integrated care is probably the most viable and effective solution for the CVD burden, ${ }^{1}$ which this part of our communities face, from prevention and screening to acute and chronic management.

Our study has several limitations. Homelessness is variably defined across studies and settings. ${ }^{22} 23$ The differences between homeless individuals and other inclusion health populations are not clear from current research, although we know there are substantial overlaps. Differences in definition of CVD, variations in treatment pathways in different contexts and the specific comparator populations are central to interpretation of results. ${ }^{824}$ The complexity of homelessness and its determinants, in addition to the knowledge gaps in epidemiology and management of CVD in homeless individuals, present steep challenges for health services and guidelines. ${ }^{8}$ Context-specific data and context-specific solutions are likely to be most beneficial in the homeless population, and as with other areas of healthcare, better use of routine electronic health record data is required. ${ }^{25}$

The 'diseases of the West' and 'diseases of affluence' paradigms persisted for many decades in global health and public health respectively, leading to neglect of non-communicable diseases and their management for several generations in those settings and populations where burden and need were greatest. ${ }^{26}$ Health service interventions for homeless people still largely focus on infectious diseases, substance abuse, mental illness and crisis management. Elevated ASMRs in CVD and other chronic diseases translate into a much greater total burden of disease and premature mortality as these events are far more common. There is wholesale neglect of chronic disease burden and management. ${ }^{27}$ We must 'think global, and act local' in this case, and this may be an example of 'reverse global health' where lessons from low-income settings with respect to vertical programmes and piggy-backing of non-communicable disease services on existing HIV/AIDS services, and focusing on both health and social care solutions, may translate to high-income settings. $^{2829}$

While we cannot wait decades for large-scale epidemiological studies before recognition of the level of the burden of CVD in these populations, such studies are required in order to understand the health service needs and policy priorities and these studies are needed in different countries, different contexts with different approaches urgently. Interventions for CVD must be pragmatic and take advantage of existing services and infrastructure (eg, OUR NIHR PDG grant). Context-specific data collection and interpretation will increase the likelihood of sustainable ways of tackling a growing issue for both high-income and low-income settings.

\section{CONCLUSION}

The burden of CVD in homeless populations is high but there are significant knowledge gaps in both research and practice. The neglect of CVD in homeless individuals is analogous to the neglect of CVD in low-income settings before large-scale epidemiological studies showed the burden of non-communicable diseases in poorer countries. The absence of interventional studies whether in specialist or integrated care programmes needs urgent attention. Further targeted observational and interventional research for CVD in the homeless will inform development of care pathways are unlikely to exist at present.

\section{Key messages}

What is already known on this subject?

- Inclusion health populations that experience considerable social exclusion such as the homeless have a large excessive mortality and morbidity

- Cardiovascular disease (CVD) is a major cause of burden of disease in all populations and in all countries, and is likely to be the same in homeless individuals.

\section{What might this study add?}

- Mortality and admissions from CVD are three times more likely in homeless individuals than housed individuals in both European countries and the USA.

- There are no interventional studies to approach CVD in the homeless population in current literature.

- There are important knowledge gaps in research and practice for CVD, which need to be addressed to inform development of management pathways and programmes.

How might this impact on clinical practice?

- Recognition of the significant burden of CVD in homeless patients.

- Development of specific CVD-related treatment and prevention pathways could be integrated into existing CVD services or existing homeless services. 


\section{Strengths and limitations of this study}

- This was a systematic literature review of studies of CVD in homeless populations.

- Both observational and interventional studies were included in the search strategy.

- Only published articles were included, not grey literature.

- Associations with CVD were not compared with associations of other non-communicable or communicable diseases.

Twitter Amitava Banerjee @amibanerjee1

Contributors The study was conceived by AB. AB, HE and NJ-AS designed the data collection tools and performed search strategy outlined. AB and NJ-AS monitored data collection, collected data, wrote the statistical analysis plan, carried out the analysis and produced the initial draft of the manuscript. AB was guarantor. All authors had full access to all data and take responsibility for the integrity and accuracy of the data analysis. All authors contributed to revision of the manuscript and accepted the final version.

Funding This study was supported by a National Institute of Health Research (NIHR) Programme Development Grant (RP-DG-0117-10003).

Competing interests None declared.

Patient and public involvement This research formed part of an NIHR Programme Development Grant with a wider patient and public engagement strategy and activities. Although patients and public were not explicitly involved in the research or the writing of the manuscript, evaluation of existing research in CVD in homeless populations was prioritised by patients and public in our preliminary work. They were involved in the dissemination of our findings.

Patient consent for publication Not required.

Provenance and peer review Commissioned; externally peer reviewed.

Data availability statement No data are available.

Open access This is an open access article distributed in accordance with the Creative Commons Attribution Non Commercial (CC BY-NC 4.0) license, which permits others to distribute, remix, adapt, build upon this work non-commercially, and license their derivative works on different terms, provided the original work is properly cited, appropriate credit is given, any changes made indicated, and the use is non-commercial. See: http://creativecommons.org/licenses/by-nc/4.0/.

\section{ORCID iDs}

Nader James Al-Shakarchi http://orcid.org/0000-0003-1496-8103

Amitava Banerjee http://orcid.org/0000-0001-8741-3411

\section{REFERENCES}

1 Luchenski S, Maguire N, Aldridge RW, et al. What works in inclusion health: overview of effective interventions for marginalised and excluded populations. Lancet 2018;391:266-80

2 Aldridge RW, Story A, Hwang SW, et al. Morbidity and mortality in homeless individuals, prisoners, sex workers, and individuals with substance use disorders in high-income countries: a systematic review and meta-analysis. Lancet 2018:391:241-50.

3 Aldridge RW, Menezes D, Lewer D, et al. Causes of death among homeless people: a population-based cross-sectional study of linked hospitalisation and mortality data in England. Wellcome Open Res 2019;4:49.

4 Lewer D, Aldridge RW, Menezes D, et al. Health-Related quality of life and prevalence of six chronic diseases in homeless and housed people: a cross-sectional study in London and Birmingham, England. BMJ Open 2019;9:e025192.

5 GBD 2017 DALYs and HALE Collaborators. Global, regional, and national disabilityadjusted life-years (DALYs) for 359 diseases and injuries and healthy life expectancy
(HALE) for 195 countries and territories, 1990-2017: a systematic analysis for the global burden of disease study 2017. Lancet 2018;392:1859-922.

6 National Institute for Health and Care Excellence(NICE). Cardiovascular disease: risk assessment and reduction, including lipid modification. Clinical guideline [CG181] 2016.

7 Cornes M, Whiteford M, Manthorpe J, et al. Improving hospital discharge arrangements for people who are homeless: a realist synthesis of the intermediate care literature. Health Soc Care Community 2018;26:e345-59.

8 Baggett TP, Liauw SS, Hwang SW. Cardiovascular Disease and Homelessness. J Am Coll Cardiol 2018:71:2585-97.

9 Roncarati JS, Baggett TP, O'Connell JJ, et al. Mortality among Unsheltered homeless adults in Boston, Massachusetts, 2000-2009. JAMA Intern Med 2018:178:1242-8.

10 Hwang SW, Wilkins R, Tjepkema M, et al. Mortality among residents of shelters, rooming houses, and hotels in Canada: 11 year follow-up study. BMJ 2009;339:b4036

11 Shamseer L, Moher D, Clarke M, et al. Preferred reporting items for systematic review and meta-analysis protocols (PRISMA-P) 2015: elaboration and explanation. BMJ 2015;350:g7647.

12 Richardson WS, Wilson MC, Nishikawa J, et al. The well-built clinical question: a key to evidence-based decisions. ACP J Club 1995;123:A12-13.

13 Zeng X, Zhang Y, Kwong JSW, et al. The methodological quality assessment tools for preclinical and clinical studies, systematic review and meta-analysis, and clinical practice guideline: a systematic review. J Evid Based Med 2015;8:2-10.

14 Oliveira LdeP, Pereira ML, Azevedo A, et al. Risk factors for cardiovascular disease among the homeless and in the general population of the city of Porto, Portugal. Cad Saude Publica 2012;28:1517-29.

15 Wilson A, Guillaumier A, George J, et al. A systematic narrative review of the effectiveness of behavioural smoking cessation interventions in selected disadvantaged groups (2010-2017). Expert Rev Respir Med 2017;11:617-30.

16 Seale JV, Fallaize R, Lovegrove JA. Nutrition and the homeless: the underestimated challenge. Nutr Res Rev 2016:29:143-51.

17 Nayyar D, Hwang SW. Cardiovascular health issues in inner City populations. Can J Cardiol 2015:31:1130-8.

18 Hwang SW, Chambers C, Katic M. Accuracy of self-reported health care use in a population-based sample of homeless adults. Health Serv Res 2016:51:282-301.

19 Kim DH, Daskalakis C, Plumb JD, et al. Modifiable cardiovascular risk factors among individuals in low socioeconomic communities and homeless shelters. Fam Community Health 2008:31:269-80.

20 Marmot M. Commission on social determinants of $\mathrm{H}$. achieving health equity: from root causes to fair outcomes. Lancet 2007;370:1153-63.

21 Health FfHal. Homeless and inclusion health standards for commissioners and service providers. 2018.

22 Argeriou M, McCarty D, Mulvey K. Dimensions of homelessness. Public Health Rep 1995:110:734-41.

23 Crisis. Chapter 3 Defining Homelessness Ended. 2018. In: Ending Homelessness [Internet]. Available: https://www.crisis.org.uk/ending-homelessness/the-plan-to-endhomelessness-full-version/background/chapter-3-defining-homelessness-ended/

24 Jones CA, Perera A, Chow M, et al. Cardiovascular disease risk among the poor and homeless - what we know so far. Curr Cardiol Rev 2009;5:69-77.

25 Richard L, Hwang SW, Forchuk C, et al. Validation study of health administrative data algorithms to identify individuals experiencing homelessness and estimate population prevalence of homelessness in Ontario, Canada. BMJ Open 2019:9:e030221.

26 Boutayeb $A$. The double burden of communicable and non-communicable diseases in developing countries. Trans R Soc Trop Med Hyg 2006;100:191-9.

27 Murray CJ, Lopez AD. Mortality by cause for eight regions of the world: global burden of disease study. Lancet 1997:349:1269-76.

28 Rao KD, Ramani S, Hazarika I, et al. When do vertical programmes strengthen health systems? A comparative assessment of disease-specific interventions in India. Health Policy Plan 2014;29:495-505.

29 Syed SB, Dadwal V, Martin G. Reverse innovation in global health systems: towards global innovation flow. Global Health 2013;9:36.

30 Corless L, Lucas L, Baraban E. Abstract P260: patients experiencing homelessness have longer Hospital lengths of stay after admission for ischemic stroke or TIA. Circulation 2017:135. 